DISTRIBUTIONAL NOTES ON HEMIPTERA, WITH THE DESCRIPTION OF A NEW GERRIS. ${ }^{1}$

\author{
By Roland F. Hussey, Forest Hills, Mass.
}

During the past three years I have collected Hemiptera in various parts of Michigan, and in the vicinity of Minneapolis and St. Paul, in Minnesota, and during this time several noteworthy captures have fallen to my lot. Some of these are reported below; records from Berrien County, in the extreme southwestern part of Michigan, have largely been omitted, however, in view of a forthcoming list of the Hemiptera taken there. I have also included here a few records, based on specimens in the collections of the Museum of Zoology of the University of Michigan, which yield important information as to the ranges of a few species. Inasmuch as the distribution of the various known species of Hemiptera in North America is as yet very imperfectly known, such records as these are of considerable value.

Published records of Hemiptera from Michigan are very few indeed--and the records from Minnesota are equally unsatisfactory. Occasional references to species which have been taken in Michigan are scattered among the reports of the proceedings of various entomological societies, but the only important list including nonaquatic forms which has appeared is that of Townsend, ${ }^{2}$ who reported ahout eighty-five species from Constantine, St. Joseph County. Some of his records, however, must be regarded as doubtful: the species reported as Neottiglossa sulcifrons Stal is undoubtedly $N$. undata (Say), which he does not list; I have taken Phymata erosa fasciata Gray and $P$. e. wolf Stal in southern Michigan, but I have seen nothing which could be considered $P$. acutangula Guérin, a Neotropical form which finds its way into Texas; the species listed as Coriscus inscriptus Kirby is probably one of the allied species of Nabis, possibly $N$. roseipennis Reuter. The Notonectæ of Townsend's list, reported as the Palaearctic

\footnotetext{
${ }^{1}$ Contribution from the Entomological Laboratory of the Bussey Institution, Harvard University, No. 179.

2 Hemiptera Collected in Southern Michigan. Proc. Ent. Soc. Wash., ii, pp. 52-56, 1891 .
} 
$N$. fabricii Fieber (= =glauca Linné) and as $N$. americana Fabricius (=indica Linné), a species occurring in the southwestern United States and Mexico, can be identified only by examination of the specimens. The same is true of the single Corixid species listed, Arctocorisa calva (Say).

However, recent work in various parts of Michigan has added materially to our knowledge of the Hemipterous fauna of the state. Collections have been made in four localities in the lower peninsula, and in the western part of the upper peninsula, along the Wisconsin border. These studies will be reported separately in the near future.

Acknowledgements are due to Messrs. H. G. Barber, J. R. de la Torre Bueno, H. M. Parshley, and H. H. Knight for identification of several of the species listed below, and to Mr. F. M. Gaige of the Museum of Zoology of the University of Michigan for permission to include several records here.

Sciocoris microphtinalmus Flor. This Pentatomid, which was first described in 1860 from the Baltic region, is widely distributed in the Palæarctic region, where it has been recorded from Europe, Russia, the Caucasus district, Siberia and China. It was first reported in America by Van Duzee in 1904, from Mt. Washington, New Hampshire, and it has since been recorded twice from Maine. Hart" lists it as occurring at Duluth, Minnesota, and in the "Lake Superior region." Stoner ${ }^{4}$ has recently given an account of its rapture at Douglas Lake, Cheboygan County, Michigan.

I have also taken this species at Douglas Lake, from roadside grasses in a lowland stand of arbor-vitæ, balsam fir, birch, and aspen; and, while I was at the University of Minnesota, Professor 0 . W. Oestlund very kindly gave me one of five specimens which he took in the vicinity of Minneapolis a number of years ago.

Very recently I have received from the Museum of Zoology of the University of Michigan a number of Hemiptera collected in North Dakota hy Mr. T. H. Hubbell during the summer of 1920 . Among these was a single specimen of S. microphthalmus, taken on the arid top of a butte in the Bad Lands near Amidon, Slope County, in the southwest corner of the state, August 21, 1920.

${ }^{3}$ The Pentatomoidea of Illinois. Bull. Ills. Nat. Hist. Surv., xiii, p. 175, 1919.

${ }^{4}$ Ent. News, xxxi, p. 141, May 1920. 
It appears probable, therefore, that this is another of the holarctic species of Hemiptera, and that its range will some day be shown to extend entirely across the American continent, as it is already known to extend across Eurasia.

Ploiariola hirtipes Banks. A specimen of this Emesine was taken from a spider-web in a cottage on Lindsley Lake, Gogebic County, Michigan, July 20, 1919 (T. H. Hubbell). This species has been reported from a number of localities in New England, but this is the first record from the central part of the continent.

Sirthenea carinata (Fabricius). There is a single specimen in the Museum of the University of Michigan, collected near Ann Arbor, August 22, 1916 (F. M. Gaige). This species has recently been reported from Illinois by Malloch, ${ }^{5}$ but without definite locality, and Osborn and Drake have recorded its occurrence in southern and central Ohio.

Atrachelus cinereus (Fabricius). During the summer of 1918 Mr. A. W. Andrews obtained two specimens of this little Reduviid near Detroit, Michigan (July 4, August 4). This species was previously known only from the southern and southeastern part of the United States.

Pagasa pallipes Stal. This Nabid, originally described from Texas, has since been reported from Kansas and Utah. On August 14, 1918, I took a single specimen at Ingleside, Cheboygan County, near the tip of the lower peninsula of Michigan. This individual lacks the obsolete pale marking on the anterior margin of the pronotum, but otherwise it agrees perfectly with the description given by Reuter and Poppius. ${ }^{6}$

Sericophanes heidemanni Poppius (= noctuans Knight). One specimen of this pretty little Mirid came to my light at Minneapolis, Minnesota, June 13, 1920. This record extends the known range of this form far to the westward. I am indebted to Dr. Knight for identification of this form.

Gerris argenticollis Parshley. This species is distributed over the eastern part of North America, from the Atlantic seaboard west at least to Michigan and Indiana. I have taken specimens in Michigan at Ann Arbor (April 19, 1919), and in the extreme

${ }^{5}$ Ent. News, xxxi, p. 240, Oct. 1920.

${ }^{6}$ Acta Soc. Sci. Fenn., ix, p. 29, 1909. 
southwestern part of the state, near Three Oaks (June to September). These were all taken from woodland pools, or from the slow-flowing stretches of the Galien River in dense woods.

Gerris alacris, sp. nov. (Fig. 1).

Facies of G. marginatus Say, a little smaller than that species, females larger and more robust than the males; commonly brachypterous. Males readily distinguished from the other North American species by the prominent omphalium of the metasternum; female easily distinguished from $G$. marginatus by the shorter spines of the sixth abdominal segment, which only slightly surpass the middle of the first genital segment.

Black above, the pronotum and the veins of the hemielytra with fine sparse golden pubescence, anterior lobe of the pronotum with a yellow median line, two small oblique yellowish marks on the base of the vertex. Bucculæ yellow, throat slate-gray; prosternum yellow, the coxal cavities with a black spot outside. Mesosternum blackish, often yellow posteriorly, commonly with two diverging yellow lines extending backward from between the anterior coxæ. Metasternum and venter yellowish, median line obsoletely carinate, the sides of the abdomen below and the region about the metasternal orifice (omphalium Bergroth 1902) blackish. The color of the ventral surface is variable: sometimes it is entirely black. Connexivum narrowly yellow outside.

Antennæ dark testaceous, first and second joints with a narrow piceous apical ring, middle of the first joint darker; apical half of the third and the entire fourth joint piceous. Relative lengths of the segments, $43: 21: 20: 30$ (average of 15 specimens). These ratios vary within narrow limits: sometimes the third segment is very slightly longer than the second, and sometimes the first is slightly shorter than the second and third together.

Legs colored as in marginatus, the middle and hind legs slightly longer than in that species. In the brachypterous form the hemielytra commonly reach to about the middle of the third abdominal segment.

Male: sinus of the sixth ventral segment similar to that of marginatus, but with the sides of the median emargination somewhat more parallel. Female: genital segment broad at the base, 
more narrowed apically than in marginatus; the spines of the sixth ventral segment rather blunt, barely surpassing the middle of the genital segment.

Length, of , $7-8 \mathrm{~mm}$., o , 9-10 mm.; greatest width (across the middle coxæ), $\hat{o}, 2.1-2.3 \mathrm{~mm}$. , $\&, 2.7-2.9 \mathrm{~mm}$.

Holotype, macropterous $\hat{\delta}$, allotype, machopterous $q$, in coll. Museum of Zoology, University of Michigan. Paratypes, 12 ô $\hat{o}$ and $18 \% q$, macropterous and brachypterous, in coll. University of Michigan Museum and R. F. Hussey.

Described from 32 specimens taken from a small pond at the foot of a sand dune on the shore of Lake Michigan near Sawyer,

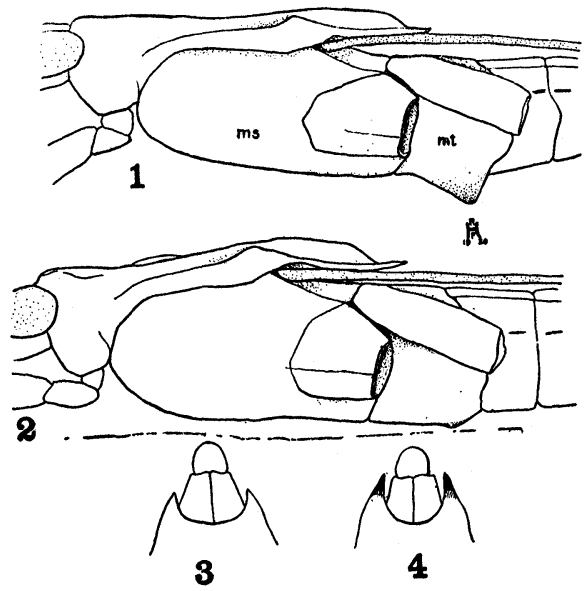

Fig. 1. 1. Thorax of Gerrls alacris, n. sp., from left side. 2. Thorax of G. marginatus Say. 3. Gerris alacris, sp. nov., female genital segments, ventral aspect. 4. G. marginatus Say, female genital segments.

Berrien County, Mich., July 19 and July 26, 1920 (R. F. Hussey). This species was by far the most coinmon water-strider here, and both adults and nymphs were seen. In company with it were G. marginatus and a few specimens of G. rufoscutellatus.

Tenagogonus hesione Kirkaldy. One adult and three nymphs of this water-strider were secured by Miss E. P. Butler at Vicksburg, Kalamazno County, Michigan, August 21, 1920. The previous North $\Lambda$ merican records were from Florida and Ohio.

Microvelia circumcincta Champion. The University of Michigan 
Museum has one specimen of this species, taken at Fort Davis, Texas, during the summer of 1914 (M. M. Sampson). This Mexican Veliid is a new addition to the Hemipterous fauna of the United States.

Microvelia buenoi Drake. This little water-strider, recently described $^{7}$ from the Adirondack Mountains, was taken on a small woodland pool near Three Oaks, Michigan, July 4, 1919; and I also found it cornmon at Minneapolis and St. Paul during May and June, 1920: I have compared these specimens with a paratype kindly given me by Professor Drake, and can find no significant differences.

Microvelia fontinalis Bueno. I have taken this species in Michigan at Ann Arbor (June 10, 1919), from a small pool in a roadside ditch below a spring, and in Berrien County (July, 1919).

Merragata foveata Drake. Apparently generally distributed over the United States east of the Rocky Mountains. I have taken it in Michigan; and I found several specimens at Minneapolis, Minnesota, on November 19, 1918-a cold, bleak day, when no other surface-dwelling Hemiptera were to be found.

Merragata brunnea Drake. The range of this species extends from Florida to New England, and west at least to Minnesota. I have taken specimens at St. Paul (Nov. 11, 1918), in Berrien and Washtenaw Counties, Michigan, and Miss Butler found it abundant at Battle Creek, Michigan, in August, 1920.

Ranatra protensa Montandon. This species has been much confused with the other two species of Ranatra which occur in northeastern North America. Its range extends from the Atlantic coast west at least to Minnesota. My Michigan specimens are from Washtenaw and Calhoun Counties, and I have seen it from St. Paul and from Cass County in Minnesota. The forms which I reported as this species from Douglas Lake 8 are $R$. americana edentula Montandon.

The present species, as I distinguish it, can be separated from R. kirkaldyi Bueno by its somewhat larger size, its more slender form, and its long and very slender fore femora, which are unbanded; it is smaller than most specimens of $R$. americana Mon-

${ }^{7}$ Bull. Brookl. Ent. Soc., xv, p. 20, 1920.

8 Occ. Papers Mus. Zool. Univ. Mich., No. 75, p. 19, 1919. 
tandon, the fore femora are more slender and have no trace of the subapical notch commonly present in that species, and the pronotum is more distinctly carinate on the posterior part of the anterior lobe. The hind legs of protensa are longer than in either of the other species, reaching to the tip of the air-tube, the femora reaching to the apices of the hemielytra, whereas in americana the legs reach only to about the middle of the air-tube and the hind femora only to the penultimate segment of the abdomen; the hind legs of kirkaldyi slightly surpass the middle of the tube.

$R$. americana is easily the most abundant species of the genus in Michigan and in Minnesota; $R$. kirkaldy $i$ is much less generally distributed, but is sometimes locally common, especially in waters containing a relatively high content of calcium salts in solution; and $R$. protensa is the least common of the three species.

Palmacorixa buenoi Abbott. This is a common Corixid in the Atlantic states, but has not hitherto been reported west of Ithaca, N. Y. During August, 1920, I took two specimens at Ann Arbor, Michigan, from among waterweeds in the Huron River.

Palmacorixa gillettei Abbott. During June and September, 1919, I found this Corixid abundant in the Galien River a few miles north of Three Oaks, Michigan. The species was previously reported only from Colorado.

Corixa verticalis (Fieber). The range of this species extends from the Atlantic coast west at least to Missouri. I found it abundant in the Galien River in June, in company with P. gillettei, but it was not taken here in September. In Mr. Bueno's collection there are two specimens from Creve Cœur Lake, Missouri, labelled Arctocorisa calva (Say) by Professor Abbott.

In his description of Palmacorixa gillettei Professor Abbott says, " "Superficially it resembles calva Say." I believe that the calva to which Professor Abbott compares his new species is certainly Corixa verticalis-especially since I have seen the specimens referred to above-since this species does have a superficial resemblance to $P$. gillettei, whereas the true calva is a very different insect.

Corixa macroceps (Kirkaldy). This species was described from

Ent. News, xxiii, p. 339, 1912. 
North Carolina, and was subsequently reported by Abbott from Georgia. Mr. Bueno has a number of specimens taken in the vicinity of New York, and Miss E. P. Butler found it abundant in a small pond near Battle Creek, Michigan, in August, 1920.

Callicorixa praeusta (Fieber). This holarctic species has several times been reported from the northern parts of America, but the only record from the United States is that of Parshley from Maine. I have seen two specimens from the Pacific coast states, one from Lake Cushman, Washington, July 3, 1919 (F. M. Gaige), in the Museum of the University of Michigan, the other from San Francisco, in Mr. Bueno's collection.

The three females which I reported from northern Michigan ${ }^{10}$ as "probably C. kollarii Fieber," should in all probability be placed in prousta. I seriously question the northern records of kollarii, which was originally described from Cuba and from Brazil.

${ }^{10}$ Occ. Papers Mus. Zool. Univ. Mich., No. 75, p. 21, 1919.

\section{OKANAGANA RIMOSA (SAY) IN NOVA SCOTIA.}

During the past summer (1920), Mr. David H. Linder, while botanizing in southern Nova Scotia, found this little Cicada at several places. In a letter he says: "It appeared to be quite common, especially in dry clearings where white birch and maple is found. About a mile north of Meteghan they were quite common in a dry clearing that had grown up to white birch and were almost numerous enough to be called a swarm. At Argyle, though not quite so thick, they were nevertheless quite common, as was also the case at Barrington, where I captured the specimen." Mteghan and Barrington are about fifty miles apart, while Argyle is nearly midway between the two places. In Nova Scotia, Mr. W. T. Davis (Journ. N. Y. Ent. Soc., 1919, vol. 2\%, p. 205) records it only from Truro.

C. W. Johnson. 

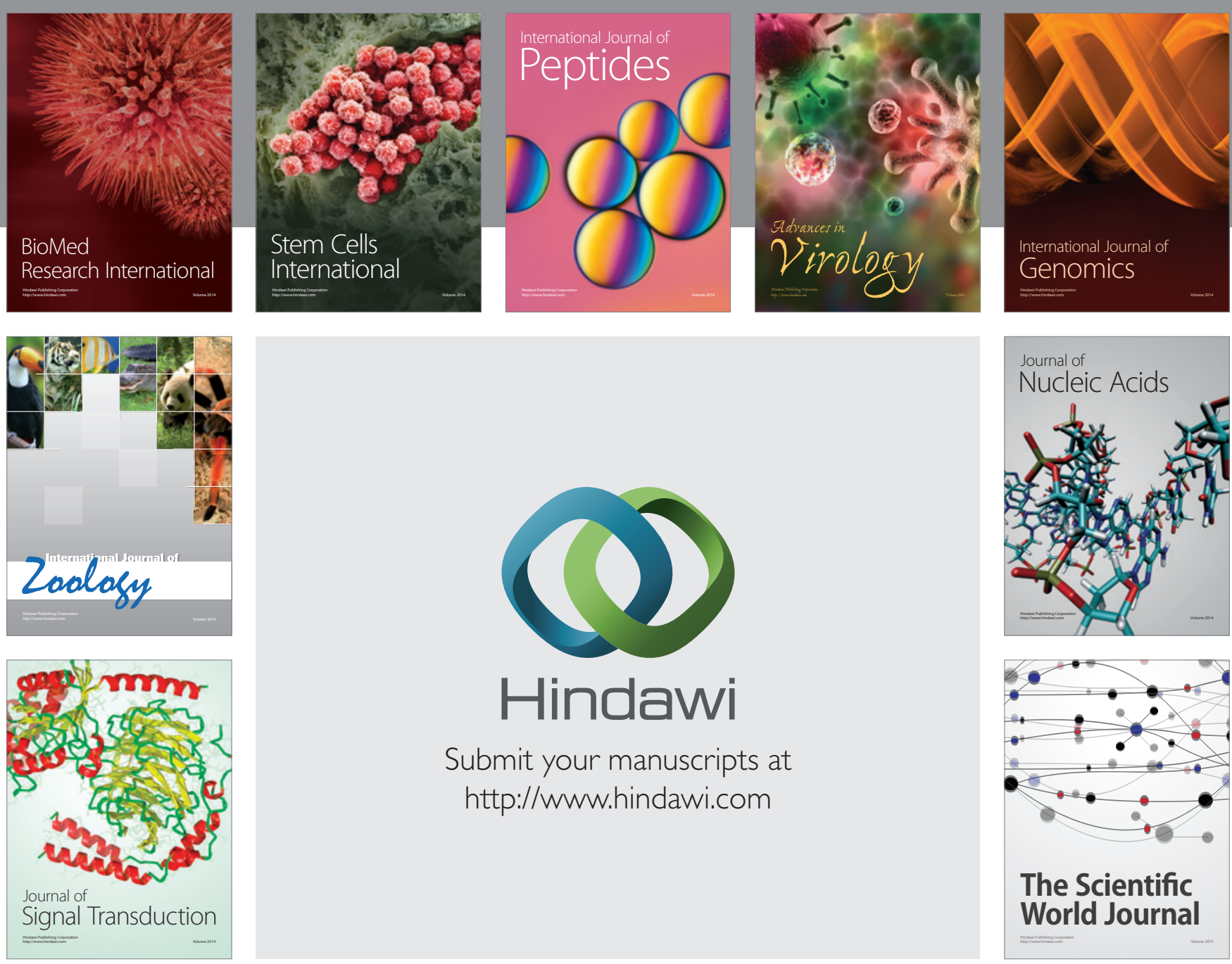

Submit your manuscripts at

http://www.hindawi.com
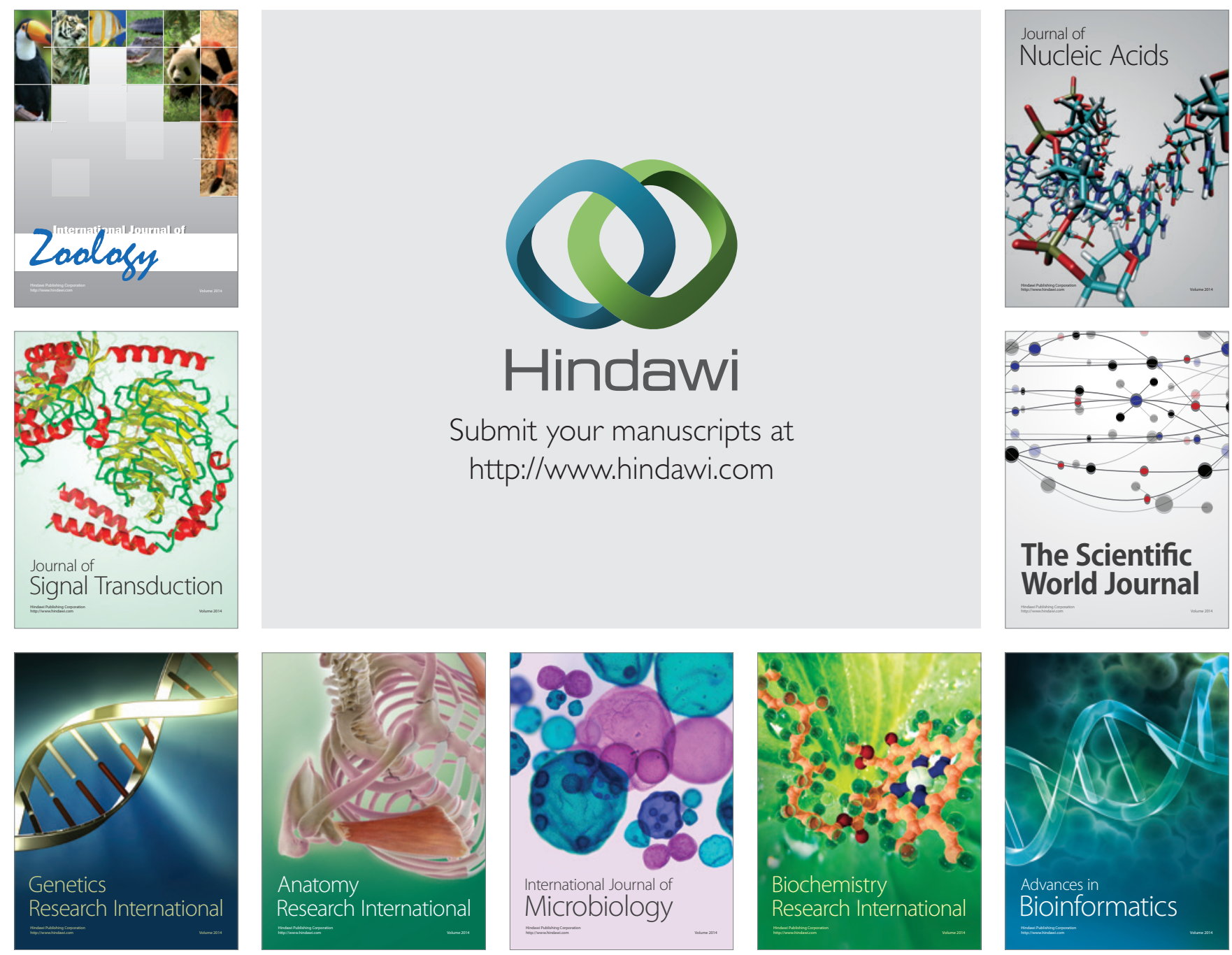

The Scientific World Journal
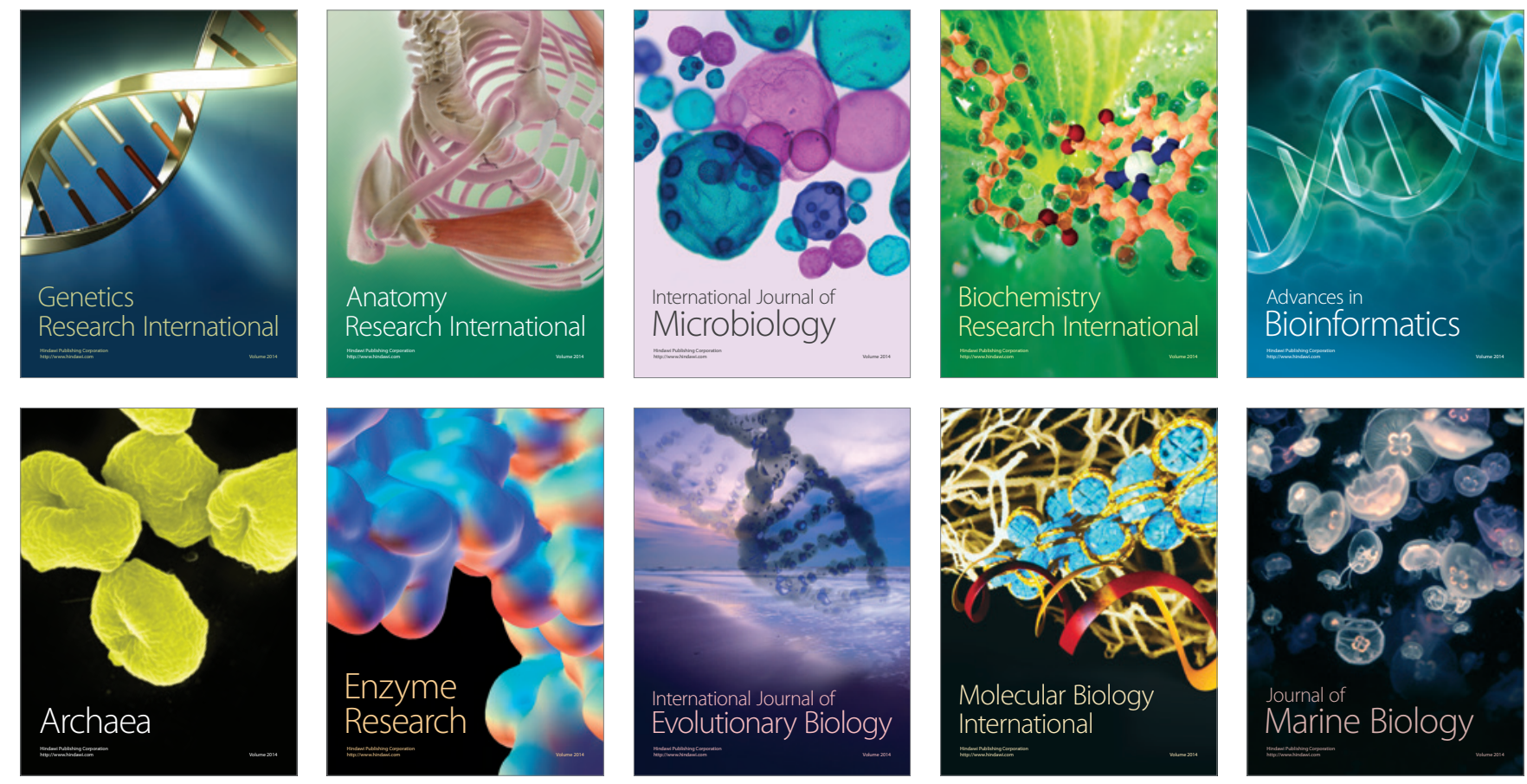